13. Wang, X. J., Zhu, D. L. and Pan, J. S., Locating concentrated seepage pipes in dam with temperature global optimization. $J$. Eng. Geol., 2015, 23(2), 335-343.

14. Wang, X. J., Li, R. Y. and Wei, S. M., Substep simulated annealing to locate multiple concentrated seepage passages in dams using ground temperature. E-J. Geotech. Eng., 2015, 20(15), 6603-6614.

15. Abu-Reesh, M. I. and Alnaizy, R., Optimal design of multi-stage bioreactors performing wastewater treatment using the MATLAB optimization. Int. J. Environ. Eng., 2015, 6(4), 403-415.

16. Dadashi, E., Ahangari, K., Noorzad, A. and Arab, A., Support system suggestion based on back-analysis results case study: Babolak water conveyance tunnel. Arab. J. Geosci., 2012, 5(6), 12971306.

17. Fernandes, F. P., Costa, M. F. P. and Fernandes, E. G. P., A derivative-free filter driven multistart technique for global optimization. Comput. Sci. Appl., Lecture Notes Comput. Sci., 2012, 7335, 103-118.

18. Takbiri, Z. and Afshar, A., Multi-objective optimization of Fusegates system under hydrologic uncertainties. Water Resour. Manage., 2012, 26(8), 2323-2345.

ACKNOWLEDGEMENTS. This study was supported by China Scholarship Council (201308410082); the National Natural Science Fund Project (41174052508902) and Henan Province and Frontier Technology Research Projects (1123004024), China.

Received 16 April 2019; revised accepted 21 December 2020

doi: $10.18520 / \mathrm{cs} / \mathrm{v} 120 / \mathrm{i} 7 / 1233-1240$

\section{Identification of begomoviruses from legume crop and weed plants and viruliferous status of the whitefly Bemisia tabaci in Central India}

\author{
Rakesh Singh Marabi ${ }^{1, *}$, Shoumitra Bikash Das ${ }^{1}$, \\ Niraj Tripathi ${ }^{2}$, Takashi Wada ${ }^{3}$ and \\ Hiroaki Noda ${ }^{3,4}$ \\ ${ }^{1}$ Department of Entomology, College of Agriculture, \\ Jabalpur 482 004, India \\ ${ }^{2}$ Directorate of Research Services, Jawaharlal Nehru Krishi Vishwa \\ Vidyalaya, Jabalpur 482 004, India \\ ${ }^{3}$ Japan International Cooperation Agency Soybean Project, \\ ADR Building Research Campus, College of Agriculture, \\ Indore 452 001, India \\ ${ }^{4}$ National Institute of Agrobiological Sciences, Owashi, \\ Ibaraki 305-8634, Japan
}

Three begomoviruses were identified based on complete genome sequence from weeds in Jabalpur, Madhya Pradesh, Central India. Alternanthera yellow vein virus (AIYVV; 2745 bp) was identified in Alter-

*For correspondence. (e-mail: rsmarabi78@ rediffmail.com) nanthera sessilis, Tobacco curly shoot virus (TbCSV; $2766 \mathrm{bp}$ ) in Sida acuta, and Cotton Leaf curl Bangalore virus (CLCuBaV; 2750 bp) in Malvastrum coromandelianum. A betasatellite DNA (1356 bp) was found associated with CLCuBaV, sharing sequence identity of $87-88 \%$ with those of other CLCuBaV isolates. TbCSV was detected in the food legumes soybean, black gram and pigeon pea, showing coinfection with Mungbean yellow mosaic India virus (MYMIV). Whitefly Bemisia tabaci, the vector of begomoviruses, harboured TbCSV and CLCuBaV at a high rate $(10-60 \%$ and $5-30 \%$ respectively). The percentage of insects harbouring MYMIV was also extremely high (60-100), indicating that the whiteflies were viruliferous for multiple begomoviruses in this region. High population density of the whitefly and intensive cultivation of crop plants promote mixed infection of various begomoviruses in the fields of Central India.

Keywords: Begomovirus, Bemisia tabaci, legumes crops, viruliferous status, weeds.

GEMINIVIRUSES (family Geminiviridae) are singlestranded DNA (ssDNA) viruses causing severe economic losses to agricultural production worldwide ${ }^{1}$. Geminiviruses possess a genome comprised of one or two circular ssDNA molecules of $2.5-2.8 \mathrm{~kb}$ (refs 2,3 ). They exhibit considerable diversity in terms of their genome structure, and are presently classified into nine genera ${ }^{4,5}$. Begomovirus is the largest genus in family Geminiviridae that includes more than 320 begomovirus species ${ }^{5}$. Many of the begomoviruses consist of two genome components, referred to as DNA-A and DNA-B ${ }^{2,6}$. Several begomoviruses were identified to have only a single component equivalent to DNA-A. However, some begomoviruses instead need another circular ssDNA component of approximately half the size of DNA-A to induce typical disease symptoms in their hosts ${ }^{3,7}$.

Begomoviruses are transmitted by the whitefly Bemisia tabaci Gennadius (Hemiptera: Aleyrodidae). This is a species complex ${ }^{8}$ and more than 35 putative species are included $^{9-12}$. The whitefly, which infests many plant species, transmits begomoviruses to various plants ${ }^{13}$. Begomoviruses are transmitted by whitefly in different crop plants in a circulative manner ${ }^{14,15}$. In Central India, $B$. tabaci is characterized as Asia I and II genetic groups ${ }^{16}$, whose population increases in the summer season (AprilJune), and viruliferous whiteflies migrate into the fields of soybean that is a major crop in the kharif season (June-September). Population density of the whitefly is generally extremely high on legume plants and weeds in the fields of Central India in this season ${ }^{17}$.

Mungbean yellow mosaic India virus (MYMIV), a member of the genus Begomovirus, causes yellow mosaic disease (YMD) in legume plants, and is a threat for important food legumes such as soybean (Glycine max), 


\section{RESEARCH COMMUNICATIONS}

green gram (mung bean, Vigna radiata), black gram (Vigna mungo), pigeon pea (Cajanus cajan), moth bean (Vigna aconitifolia), and common bean (Phaseolus vulgaris $)^{18,19}$. YMD is highly prevalent and is a big constraint for legume crop yield in Madhya Pradesh, Central India, which is the major food legume production area of the country ${ }^{20}$.

A large number of begomoviruses have been reported from India, probably in part due to its warm tropical climate supporting year-round survival of the whitefly vector and intensive crop cultivation ${ }^{21,22}$. Yellow mosaic, vein yellowing, mottling or distortion, which are typical symptoms of begomoviruses in diseased plants, are frequently observed in weeds growing on the bunds/terraces and in the legume crop fields in Madhya Pradesh. In this study, we have characterized three begomoviruses from the weeds collected near soybean fields, where outbreak of MYMIV had occurred. Infection status of the begomoviruses in plants and viruliferous rates in whitefly populations were examined. The present study reveals that viruliferous rates of $B$. tabaci with MYMIV populations are quite high and whiteflies also harbour other begomoviruses in Central India.

Three species of weeds showing symptoms typical of those induced by begomoviruses were collected in the campus of Jawaharlal Nehru Krishi Vishwa Vidyalaya (JNKVV), College of Agriculture, Jabalpur, Madhya Pradesh. Alternanthera sessilis showing yellow vein symptoms was collected from the bund of a crop field during July 2012. Sida acuta showing yellow mosaic symptoms and Malvastrum coromandelianum showing yellow vein symptoms were collected from the roadside near crop fields during July 2015.

For PCR diagnosis of begomoviruses, leaf samples were collected from the fields in Madhya Pradesh. Sites and dates of collection are given in the Supplementary Table 1. Whiteflies were collected from experimental fields of JNKVV and farmer's fields in Madhya Pradesh, and preserved in acetone at $4^{\circ} \mathrm{C}$ until use. Whitefly collection sites and dates are given in the Supplementary Table 2.

Total DNA of A. sessilis was isolated using CTAB method $^{23}$, whereas DNA of S. acuta and M. coromandelianum was simply isolated by crushing a small leaf disc (ca. $\left.2 \mathrm{~cm}^{2}\right)$ with STE buffer (10 mM Tris $\mathrm{HCl}(\mathrm{pH} 8.0)$ containing $1 \mathrm{mM}$ ethylenediaminetetraacetic acid $(\mathrm{pH}$ 8.0) and $10 \mathrm{mM} \mathrm{NaCl}$ ) and proteinase $\mathrm{K}$ (Merck Millipore) digestion, which is often used for DNA extraction in insects ${ }^{16}$. The DNA solution was then phenol-extracted and ethanol-precipitated. DNA templates for sequencing were prepared using different methods for three viruses from A. sessilis, S. acuta and M. coromandelianum.

First, DNA isolated from A. sessilis was amplified by multiple displacement amplification using REPLI-g Mini Kit (Qiagen, Hilden) to obtain begomovirus genome DNA. The amplified DNA was enzyme-cut and electro- phoresed on $1 \%$ agarose gel. The enzyme treatment produced DNA fragments of 1600 and $1200 \mathrm{bp}$ by the restriction enzyme BamHI, 2200 and 600 by EcoRI, and $1400 \mathrm{bp}$ by $P s t \mathrm{I}$, suggesting that the expected size (ca. 2800) of DNA was amplified. These DNA fragments were cloned into BamHI, EcoRI or PstI cloning site of pBluescript II (Stratagene, California) respectively, following dephosphoration of the vector using calf intestinal alkaline phosphatase (Toyobo, Tsuruga, Japan). T3 and T7 primers were used for sequencing together with BigDye Primer Cycle Sequencing kit (Applied Biosystems, Life Technologies, USA). Sequencing was performed in a DNA analyzer (model 3700, Applied Biosystems).

Second, DNA of $S$. acuta was used to amplify DNA-A of begomovirus employing universal primers designed on capsid protein $(A V 1)$ gene of DNA-A ${ }^{24}$, DNA-A_Univ-f and DNA-A_Univ-r (Supplementary Resource 1). PCR was first performed using PrimeSTAR Max DNA polymerase (Takara Bio Inc., Shiga) in $20 \mu 1$ reaction volume under the condition of initial $1 \mathrm{~min}$ at $94^{\circ} \mathrm{C}$, followed by five cycles of $20 \mathrm{sec}$ at $94^{\circ} \mathrm{C}, 20 \mathrm{sec}$ at $60^{\circ} \mathrm{C}$ and $3 \mathrm{~min}$ at $72^{\circ} \mathrm{C}$; five cycles of $20 \mathrm{sec}$ at $94^{\circ} \mathrm{C}, 20 \mathrm{sec}$ at $56^{\circ} \mathrm{C}$ and $3 \mathrm{~min}$ at $72^{\circ} \mathrm{C} ; 28$ cycles of $20 \mathrm{sec}$ at $94^{\circ} \mathrm{C}, 20 \mathrm{sec}$ at $52^{\circ} \mathrm{C}$ and $3 \mathrm{~min}$ at $72^{\circ} \mathrm{C}$, and $3 \mathrm{~min}$ at $72^{\circ} \mathrm{C}$ for final extension. Since no PCR product was visible on the agarose gel, a second PCR using $0.5 \mu \mathrm{l}$ of the first PCR solution and the same primers with Ex-Taq (Takara Bio Inc., Japan) was performed under the condition of an initial $1 \mathrm{~min}$ at $94^{\circ} \mathrm{C}$, followed by $20 \mathrm{sec}$ at $94^{\circ} \mathrm{C}, 20 \mathrm{sec}$ at $56^{\circ} \mathrm{C}$ and $1 \mathrm{~min}$ at $72^{\circ} \mathrm{C}$ for 32 cycles, and $3 \mathrm{~min}$ at $72^{\circ} \mathrm{C}$ for final extension. The reaction mixture for Ex-Taq consisted of $25 \mu$ l of PCR buffer (10 mM Tris- $\mathrm{HCl}$ ( $\mathrm{pH} 8.0)$; $50 \mathrm{mM}$ potassium chloride $(\mathrm{KCl}) ; 1.5 \mathrm{mM}$ magnesium chloride $\left.\left(\mathrm{MgCl}_{2}\right)\right), 0.25 \mathrm{mM}$ of each dNTP, 10 pmol each of primers and $1 \mathrm{U}$ of DNA polymerase. The amplified product of expected size (2700-2800 bp) was cloned into pGEM-T. The insert DNA was amplified using M13-20 and M13-reverse primers, and sequenced from both ends using SP6 and T7 primers. The inner part of the DNA inserts of $S$. acuta virus was further sequenced using two sequence primers, Sa_seq_f and Sa_seq_r (Supplementary Resource 1). There remained about $80 \mathrm{bp}$ gap in the region of universal primers. A primer set, Sa_gap_f and Sa_gap_r, was designed to fill this gap (Supplementary Resource 1), and the PCR product amplified using this primer set was sequenced.

Finally, DNA-A of begomovirus from M. coromandelianum was obtained employing the same approach as that of $S$. acuta virus using the universal primers, DNAA_Univ-f and DNA-A_Univ-r. To further confirm the sequences, four specific primer sets, DNA-A_Univ-f/ Mc_r2, Mc_f1/Mc_r1, Mc_f2/DNA-A_Univ-r and Mc_f2/Mc_r2 were designed (Supplementary Resource 1). PCR condition was the same as that described above for Ex-Taq. The PCR products were cloned into pGEM-T and the sequence was determined as described above. 


\section{RESEARCH COMMUNICATIONS}

Betasatellite was amplified from $M$. coromandelianum using the primers $\beta 01$ and $\beta 02$ (Supplementary Resource 1). Using Ex-Taq in $25 \mu \mathrm{l}$ solution, PCR condition was as follows: initial $1 \mathrm{~min}$ at $94^{\circ} \mathrm{C}$, followed by five cycles of $30 \mathrm{sec}$ at $94^{\circ} \mathrm{C}, 30 \mathrm{sec}$ at $58^{\circ} \mathrm{C}$ and $2 \mathrm{~min}$ at $72^{\circ} \mathrm{C}$; five cycles of $20 \mathrm{sec}$ at $94^{\circ} \mathrm{C}, 20 \mathrm{sec}$ at $53^{\circ} \mathrm{C}$ and $2 \mathrm{~min}$ at $72^{\circ} \mathrm{C} ; 25$ cycles of $20 \mathrm{sec}$ at $94^{\circ} \mathrm{C}, 20 \mathrm{sec}$ at $48^{\circ} \mathrm{C}$ and $2 \mathrm{~min}$ at $72^{\circ} \mathrm{C}$, and $3 \mathrm{~min}$ at $72^{\circ} \mathrm{C}$ for final extension. PCR product of about $1350 \mathrm{bp}$ was cloned into pGEM-T and the insert DNA was sequenced using SP6 and T7 primers as described above.

To determine the sequence at the primer annealing regions in the betasatellite DNA, specific primers Mc_beta_gap-f and Mc_beta_gap-r were designed to cover the gap region (Supplementary Resource 1). The DNA of the gap region was amplified under the PCR condition of initial $1 \mathrm{~min}$ at $94^{\circ} \mathrm{C}$, followed by 35 cycles of $20 \mathrm{sec}$ at $94^{\circ} \mathrm{C}, 20 \mathrm{sec}$ at $56^{\circ} \mathrm{C}$ and $1 \mathrm{~min}$ at $72^{\circ} \mathrm{C}$, and $3 \mathrm{~min}$ at $72^{\circ} \mathrm{C}$ for final extension. The PCR product was cloned into pGEM-T and sequenced as described above.

Almost all plant DNA was extracted from leaves (1-1.5 $\left.\mathrm{cm}^{2}\right)$ using a DNeasy Plant Mini Kit (QIAGEN). DNA of one sample collected from A. sessilis in 2012 was prepared using the CTAB method. Whitefly DNA was prepared by crushing individual whiteflies in an Eppendorf tube with $30 \mu \mathrm{l}$ of STE buffer. Proteinase K (Merck Millipore, USA; $2 \mu \mathrm{l}$ of $10 \mathrm{mg} / \mathrm{ml}$ ) was added and the solution was incubated at $55^{\circ} \mathrm{C}$ for $30 \mathrm{~min}$ and then $95^{\circ} \mathrm{C}$ for 5 min (ref. 16 ).

PCR assays were performed using $1 \mu \mathrm{l}$ of each extracted solution (template DNA) in a total reaction volume of $25 \mu \mathrm{l}$. PCR was performed using $2 \times$ PCR Taq Mixture (HiMedia Laboratories, Mumbai, India) or Ex-Taq with 10 pmol of each forward and reverse primer. PCR conditions were initial $1 \mathrm{~min}$ at $94^{\circ} \mathrm{C}$, followed by $20 \mathrm{sec}$ at $94^{\circ} \mathrm{C}, 20 \mathrm{sec}$ at $54-56^{\circ} \mathrm{C}$ and $1 \mathrm{~min}$ at $72^{\circ} \mathrm{C}$ for $32-34$ cycles and $3 \mathrm{~min}$ at $72^{\circ} \mathrm{C}$ for final extension. PCR products were separated on $1 \%$ agarose gel visualized by ethidium bromide staining and photographed under a UV transilluminator.

Primers used for PCR of DNA-A of three viruses and DNA-A and DNA-B of MYMIV are shown in the Supplementary Resource 1. Two primer pairs were used for DNA-A of MYMIV; one is for detecting DNA of capsid protein $(A V l)$ gene region (MYMVcpFwd and MYMVcpRev), and the other for detecting DNA of a part of the common region and $A V 2$ gene region (MYMiV_sp_f1 and MYMiV_sp_r2). Positive control primer sets were also used for legume plants and whitefly in order to validate template DNA quality. Primer set for starch branching enzyme ( $S B E$ ) gene (SBE-f and SBE-r), which was newly designed based on the sequences from the soybean $S B E$ gene, amplified about 480 bp DNA from legume plants but not from weeds. Primer set for cytochrome oxidase I (COI) gene (BtCOI_f and BtCOII_r) amplified 949 bp DNA from mitochondrial genome of the whitefly ${ }^{16}$. The samples in which positive PCR reaction was not observed using these primer sets were not used for further diagnostic PCR in plants and not included for calculation of viruliferous rates in whitefly.

Phylogenetic analyses were done for genomes of the three begomoviruses from A. sessilis, S. acuta and $M$. coromandelianum (Alt-DNA-A, Sida-DNA-A and MalDNA-A respectively) to determine their phylogenetic relationship. Complete sequences of DNA-A from some begomoviruses (genus Begomovirus) were retrieved from GenBank at the National Center for Biotechnology Information (NCBI, USA). A total of 36 sequences of DNA-A, including four newly sequenced DNA-A of the three virus species were aligned using Clustal $X^{25}$. The alignments were then inspected and corrected manually and all gap sites in the alignments were removed, resulting in 2488 aligned nucleotide sites.

Phylogenetic analyses were done using PhyML 3.0 online (http://www.atgc-montpellier.fr/phyml/) ${ }^{26}$. The maximum likelihood (ML) estimation was performed under default settings with HKY-85 model. Bootstrap tests were conducted by 500 resamplings for ML. Analyses were also done employing the neighbor-joining (NJ) method in PHYLIP (http://evolution.genetics.washington.edu/ phylip.html) using Kimura's 2-parameter model. Bootstrap tests were conducted by 1,000 resamplings for NJ.

Percentage identity was calculated between two virus sequences using Sequence Demarcation Tool (SDT) ${ }^{27}$. Pairwise sequence alignment of two selected viruses was performed using MUSCLE in SDT ${ }^{28}$.

Two similar sequences, Alt-DNA-A_a (accession number LC316182) and Alt-DNA-A_b (LC316183), were obtained from A. sessilis. Both were circular DNA of 2745 bp. Percentage identity between them was 95.8 (Supplementary Resource 2), which suggests that the two DNA-A sequences are different isolates of the same spe$\operatorname{cies}^{13}$. These two virus DNA sequences showed the highest percentage identity with Alternanthera yellow vein virus (AlYVV) genome (accession number LN795903) and the second highest also with AlYVV (KT717678) through BlastN homology searches. The phylogenetic analyses showed that Alt-DNA-A_a and Alt-DNA-A_b formed a monophyletic group with AlYVV (Figure 1). Percentage identities of Alt-DNA-A_a and Alt-DNA-A_b against LN795903, the most closely related virus sequence, were 95.2 and 94.0 respectively, which are larger than the demarcation threshold for different species (91) and larger than or equal to that for different strains $(94)^{13}$. The result confirms the higher resemblance of these two isolates with AIYVV.

Begomovirus DNA-A amplified from S. acuta, SidaDNA-A (LC316184), was 2766 bp and showed highest percentage identity with Tobacco curly shoot virus (TbCSV) (KM383753). Phylogenetic analysis also showed a close relation with TbCSV (Figure 1). Percentage identity of Sida-DNA-A against KM383753 was 


\section{RESEARCH COMMUNICATIONS}

92.6, indicating that this begomovirus is a strain of TbCSV.

Circular DNA obtained from $M$. coromandelianum, Mal-DNA-A (LC316185), was 2750 bp. BlastN search showed highest percentage identity with Cotton leaf curl Bangalore virus (CLCuBaV; AY705380), followed by CLCuBaV (GU112003) and Malvastrum yellow vein Chitwan virus (MYVChV; JQ327840 and JQ327841). Phylogenetic analysis showed that Mal-DNA-A formed a monophyletic group with CLCuBaV (AY705380 and GU112003). Some other begomoviruses, e.g. Hollyhock leaf curl virus (HoLCuV; FR772082), Pea leaf distortion virus (PLDV; KY001641) and MYVChV (JQ327840 and JQ327841) were close relatives (Figure 1). Percentage identity scores were compared between Mal-DNA-A and DNA-A of these phylogenetically close viruses (Supplementary Resource 2). CLCuBaV (AY705380) showed the highest percentage identity of 90.8 followed by CLCuBaV (GU112003; 90.0) and MYVChV (JQ327840; 90.0). The recently proposed demarcation threshold for begomovirus species is $91 \%$ based on pairwise sequence comparison with exclusion of gap sites. The identity value $90.8 \%$ is close to $91 \%$, and therefore it seems reasonable to define this virus as CLCuBaV. This is also

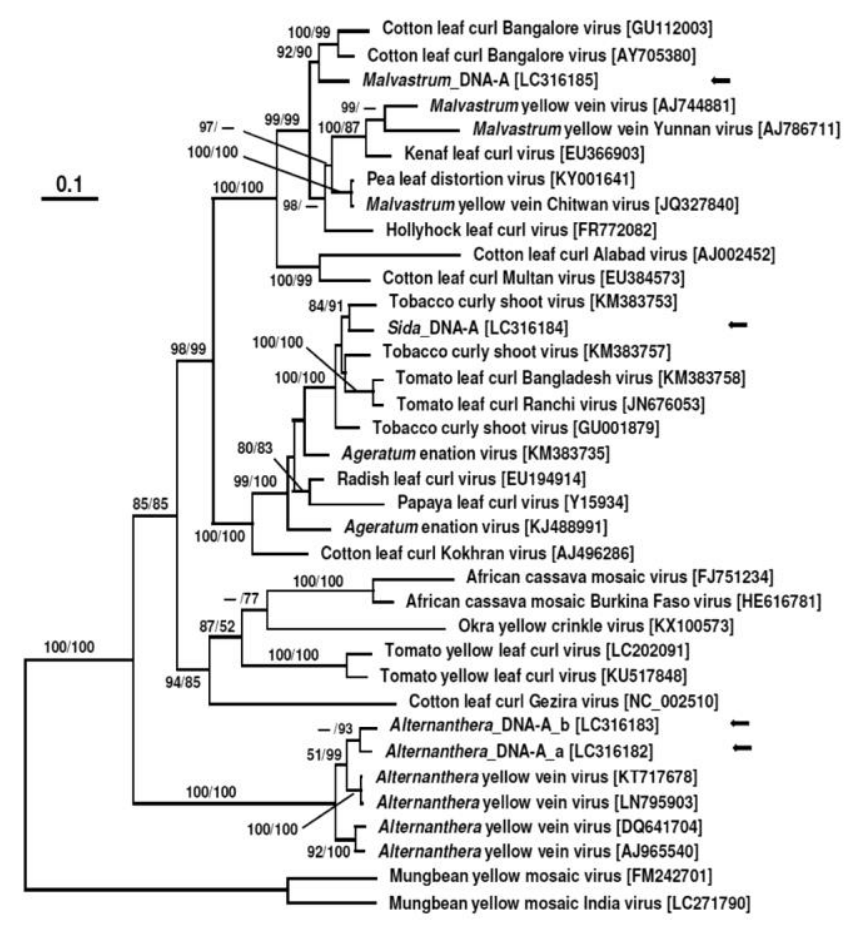

Figure 1. Phylogenetic analysis of DNA-A sequences isolated from weeds based on the DNA-A sequences of begomoviruses. Four newly analysed sequences (arrows) were used with 32 DNA-A sequences in the DNA databases. In total 2,488 aligned nucleotide sites were subjected to the analysis. A maximum likelihood (ML) phylogeny (unrooted tree) is shown and neighbor-joining (NJ) analysis gives substantially the same results. Statistical support values $>50 \%$ are shown at the nodes in the order of ML/NJ. Accession numbers are indicated in parenthesis. supported by the fact that the identity score, including gaps between Mal-DNA-A and AY705380 was 90.2\%, which is larger than the species demarcation criterion that has been used conventionally $(89 \%)^{17}$. In addition, identity in putative amino acid sequence of capsid protein between Mal-DNA-A and CLCuBaV (AY705380) was very high $(97.3 \%)$.

The expected size $(1350 \mathrm{bp})$ of PCR product for betasatellite DNA was obtained from $M$. coromandelianum using the general primer pair for betasatellite. This betasatellite DNA of 1356 bp (LC316186) encoded the $\beta$-C1 gene in the complementary sense DNA, and showed two well-known features, viz. the presence of a potential stem-loop structure containing the ubiquitous nonanucleotide sequence TAATATTAC in the conserved region and the presence of a sequence rich in adenine (A-rich) ${ }^{29}$. It showed high identity with CLCuBaV-associated betasatellite DNA (AY705381 (ref. 30) and KC608158), whose associated DNA-A components were those of AY705380 and GU112003 (CLCuBaV) described above respectively. Pairwise sequence percentage identities against AY705381 and KC608158 were 87.8 and 87.5 respectively. The result strongly suggests that this betasatellite is a cognate satellite of Mal-DNA-A (CLCuBaV).

In order to know whether plants in the field are infected with these viruses, some crops and weeds were PCR-tested. Sample template integrity was first examined using the primer pair for starch branching enzyme $(S B E)$ gene in soybean, black gram and wild black gram (Vigna trilobata), and not in weed plants A. sessilis, S. acuta and $M$. coromandelianum, since this primer pair did not amplify $S B E$ gene in these weed plant samples. In addition to testing DNA-A of the three viruses (AlYVV, TbCSV and CLCuBaV), DNA-A and DNA-B of MYMIV were also examined (Supplementary Table 1).

AlYVV was only detected in A. sessilis, which was collected on July 2012 in Jabalpur. TbCSV was detected in soybean, black gram and pigeon pea, which were collected in 2014 and 2015. CLCuBaV was detected in $S$. acuta and $M$. coromandelianum. MYMIV infected soybean, black gram, pigeon pea, V. trilobata and A. sessilis; both DNA-A and DNA-B of MYMIV were detected in each plant sample.

Whiteflies were collected from a fixed location (JNKVV) or different locations during main cultivating seasons of legume crops. In Madhya Pradesh, soybean, green gram and black gram are mainly cultivated in the kharif season, but the latter two crops are also cultivated in the summer season. Twenty whiteflies were used for PCR from each collection and PCR-positive samples using COI primer pair were used for calculating viruliferous rates for individual viruses. Viruliferous changes for each virus in the whiteflies are summarized in the Supplementary Table 2. PCR for individual whiteflies are also shown in the Supplementary Resource 3. 
Whiteflies showed extremely high infection rates for MYMIV (60-100\%). In summer and kharif seasons, MYMIV is prevalent in many legume crops, especially soybean, green gram and black gram. AlYVV, however, was not detected in any whiteflies in this survey in 2015. The reason is unclear. Infection rate of TbCSV varied among the collections, being highest at $60 \%$ at a black gram field in Shahpura, Jabalpur during early June 2015. CLCuBaV showed infection rates ranging from $5 \%$ to $30 \%$. Many individual whiteflies harboured multiple viruses; some whiteflies had three viruses, i.e. TbCSV, CLCuBaV and MYMIV (Supplementary Resource 3).

Three begomoviruses, AlYVV, TbCSV and CLCuBaV, and a CLCuBaV-associated betasatellite were found in weeds. AlYVV which was isolated from A. sessilis in the present study was first reported in 2005 from an aquatic plant, A. philoxeroides, in Hainan Province, China ${ }^{31}$. AlYVV was then found in the water primrose (Ludwigia hyssopifolia) ${ }^{32}$, common zinnia (Zinnia elegans) and false daisy (Eclipta prostrate) $)^{33,34}$ in China and/or Vietnam. In Pakistan, AlYVV was found in field sowthistle (Sonchus arvensis $^{35}$ and E. prostrata ${ }^{36}$.

TbCSV was first found in tobacco in Yunnan Province, China $^{37}$. It infects important crops, viz. tobacco (Nicotiana tabacum), tomato (Solanum lycopersicum) ${ }^{38,39}$ and pepper (Capsicum frutescens) ${ }^{40}$. TbCSV is reported to infect common bean (Phaseolus vulgaris) and tomato in India $^{41,42}$, and was detected in soybean, black gram and pigeon pea (Supplementary Table 1). Since TbCSV has the potential to infect legume crops, infection survey in field crops and elucidating the relation with MYMIV are important issues in Central India.

The begomovirus found in $M$. coromandelianum (Mal-DNA-A) was defined as a strain of CLCuBaV based on phylogenetic analyses (Figure 1) and percentage identity (Supplementary Resource 2). Association with a betasatellite which shows high homology with that of CLCuBaV also supports the fact that the present virus is a strain of CLCuBaV. Also, CLCuBaV (AY705380) was first found in cotton (Gossypium barbadense) in southern India $^{43}$. An isolate of CLCuBV (GU112003) found in leaves in okra (Abelmoschus esculentus) is reported to infect hollyhock (Althaea rosea), Nicotiana species and okra. This isolate did not show infection in cotton $G$. herbaceum and $M$. coromandelianum by whitefly inoculation tests. Isolates of $\mathrm{CLCuBaV}$ are suggested to be of recombinant origin ${ }^{44,45}$

The whitefly $B$. tabaci feeds on a wide range of host plants of families ${ }^{46,47}$, showing highly different biological, physiological and genetic features among strains. It is divided into many genetic groups based on mitochondrial COI gene sequences. B. tabaci populations in Central India mainly comprise Asian I and Asian II groups ${ }^{16,30,48,49}$. Since the whitefly retains multiple begomoviruses (Supplementary Resource 3), it could inoculate more than one begomovirus to many plants. High density of white- fly populations and high viruliferous rate for some begomoviruses in Central India (Supplementary Table 2) may provide many virus-reservoir plants. Actually, MYMIV can be detected in many non-legume plants; for example, from eggplant, cotton and weeds ${ }^{16}$. TbCSV was detected in some of the food legumes, soybean, black gram and pigeon pea (Supplementary Table 1). However, little knowledge is available about whitefly preference for host plants in Central India, which is important for virus transmission. Analysis of whitefly movement among legume plants, and between legume and non-legume plants will provide helpful knowledge for the prevalence of begomoviruses in this region.

The tripartite association among begomoviruses, host plants and whitefly vector appears to provide additional complexity by begomovirus evolution. The genome organization is common among begomoviruses ${ }^{2,50}$ and genetic exchange often occurs producing many kinds of virus variants ${ }^{6,51,52}$. The Indian subcontinent seems to be a melting pot of begomoviruses and such varied viruses are produced through gene exchange, genetic reassortment and mutation. The results of the present study indicate that TbCSV was detected from soybean, black gram and pigeon pea. CLCuBaV, however, was not detected from legume plants, as far as the present limited samples are concerned. Both TbCSV and CLCuBaV can be transmitted by the whitefly, whereas CLCuBaV may lack the ability to survive in plants of family Fabaceae. The virus host limitation and genetic isolation of begomoviruses in plant families are important features for disease prevalence $^{19}$. Since the whitefly contains multiple viruses, host plant selection of the whitefly and host range of the viruses are important issues to be explored.

Conflict of interest: The authors declare no conflict of interest.

1. Rojas, M. R., Hagen, C., Lucas, W. J. and Gilbertson, R. L., Exploiting chinks in the plant's armor: evolution and emergence of geminiviruses. Annu. Rev. Phytopathol., 2005, 43, 361-394.

2. Hanley-Bowdoin, L., Bejarano, E. R., Robertson, D. and Mansoor, S., Geminiviruses: masters at redirecting and reprogramming plant processes. Nature Rev. Microbiol., 2013, 11, 777-788.

3. Nawaz-ul-Rehman, M. S. and Fauquet, C. M., Evolution of geminiviruses and their satellites. FEBS Lett., 2009, 583, 18251832.

4. ICTV, Virus taxonomy: 2016 release. International Committee on Taxonomy of Viruses, Hungary, 2016.

5. Zerbini, F. M. et al. and ICTV Report Consortium, ICTV virus taxonomy profile: Geminiviridae. J. Gen. Virol., 2017, 98, 131133.

6. Malathi, V. G., Biology and pathogenesis of begomoviruses. J. Mycol. Plant Pathol., 2015, 45, 123-143.

7. Zhou, X., Advances in understanding begomovirus satellites. Annu. Rev. Phytopathol., 2013, 51, 357-381.

8. Lee, W., Park, J., Lee, G. S., Lee, S. and Akimoto, S., Taxonomic status of the Bemisia tabaci complex (Hemiptera: Aleyrodidae) and reassessment of the number of its constituent species. PLoS ONE, 2013, 8, e63817. 
9. De Barro, P. J., Liu, S. S., Boykin, L. M. and Dinsdale, A. B., Bemisia tabaci: a statement of species status. Annu. Rev. Entomol. 2011, 56, 1-19.

10. Firdaus, S., Vosman, B., Hidayati, N., Supena, E. D. J., Visser, R. G. F. and Van Heusden, A. W., The Bemisia tabaci species complex: additions from different parts of the world. Insect Sci., 2013, 20, 723-733.

11. Liu, S. S., Colvin, J. and De Barro, P. J., Species concepts as applied to the whitefly Bemisia tabaci systematics: how many species are there? J. Integr. Agric., 2012, 11, 176-186.

12. Luan, J. B., Wang, X. W., Colvin, J. and Liu, S. S., Plant-mediated whitefly-begomovirus interactions: research progress and future prospects. Bull. Entomol. Res., 2014, 104, 267-276.

13. Brown, J. K. et al., Revision of begomovirus taxonomy based on pairwise sequence comparisons. Arch. Virol., 2015, 160, 1593 1619.

14. Ghanim, M., Morin, S. and Czosnek, H., Rate of Tomato yellow leaf curl virus translocation in the circulative transmission pathway of its vector, the whitefly Bemisia tabaci. Phytopathology, 2001, 91, 188-196.

15. Kliot, A. and Ghanim, M., The role of bacterial chaperones in the circulative transmission of plant viruses by insect vectors. Viruses, 2013, 5, 1516-1535.

16. Ansari, P. G., Singh, R. K., Kaushik, S., Krishna, A., Wada, T. and Noda, H., Detection of symbionts and virus from the whitefly Bemisia tabaci (Hemiptera: Aleyrodidae), the vector of Mungbean yellow mosaic India virus in Central India. Appl. Entomol. Zool., 2007, 52, 567-579.

17. Karthikeyan, A., Shobhana, V. G., Sudha, M., Raveendran, M., Senthil, N., Pandiyan, M. and Nagarajan, P., Mungbean yellow mosaic virus (MYMV): a threat to green gram (Vigna radiata) production in Asia. Int. J. Pest Manage., 2015, 60, 314-324.

18. Varma, A., Dhar, A. and Mandal, B., MYMV transmission and control in India. In Mungbean Yellow Mosaic Disease. Proceeding of the International Workshop, Bankok Asian Vegetable Research and Development Center, Taipei, 1992, pp. 8-27.

19. Mandal, B., Varma, A. and Malathi, V. G., Systemic infection of Vigna mungo using the cloned DNAs of mungbean yellow mosaic geminivirus through agroinoculation and transmission of the progeny virus through whiteflies. J. Phytopathol., 1997, 145, 505-510.

20. Ramesh, S. V., Chouhan, B. S., Gupta, G. K., Ramteke, R., Chand, S. and Husain, S. M., Molecular diversity analysis of coat protein gene encoded by legume begomoviruses and PCR assay to detect yellow mosaic viruses infecting soybean in India. Br. Biotech. J., 2016, 12, 1-10.

21. Borah, B. K. and Dasgupta, I., Begomovirus research in India: a critical appraisal and the way ahead. J. Biosci., 2012, 37, 791-806.

22. Malathi, V. G. et al., Begomoviruses and their satellites occurring in India: distribution, diversity and pathogenesis. In A Century of Plant Virology in India (eds Mandal, B. et al.), Springer Nature Singapore Pte Ltd., 2017, pp. 75-177; https://doi.org/10.1007/978981-10-5672-75.

23. Murray, M. G. and Thompson, W. F., Rapid isolation of high molecular weight plant DNA. Nucleic Acids Res., 1980, 8, 43214325 .

24. Briddon, R. W. and Markham, P. G., Universal primers for the PCR amplification of dicot-infecting geminiviruses. Mol. Biotechnol., 1994, 1, 202-205.

25. Larkin, M. A. et al., Clustal W and Clustal X version 2.0. Bioinformatics, 2007, 23, 2947-2948.

26. Guindon, S., Dufayard, J. F., Lefort, V., Anisimova, M., Hordijk, W. and Gascuel, O., New algorithms and methods to estimate maximum-likelihood phylogenies: assessing the performance of PhyML 3.0. Syst. Biol., 2010, 59, 307-321.

27. Muhire, B. M., Varsani, A. and Martin, D. P., SDT: a virus classification tool based on pairwise sequence alignment and identity calculation. PLoS ONE, 2014, 9, e108277.
28. Edgar, R. C., MUSCLE: multiple sequence alignment with high accuracy and high throughput. Nucleic Acids Res., 2004, 32, 1792-1797.

29. Briddon, R. W., Bull, S. E., Mansoor, S., Amin, I. and Markham, P. G., Universal primers for the PCR-mediated amplification of DNA beta: a molecule associated with some monopartite begomoviruses. Mol. Biotechnol., 2002, 20, 315-318.

30. Chowda-Reddy, R. V., Kirankumar, M., Seal, S. E., Muniyappa, V., Valand, G. B., Govindappa, M. R. and Colvin, J., Bemisia tabaci phylogenetic groups in India and the relative transmission efficacy of Tomato leaf curl Bangalore virus by an indigenous and an exotic population. J. Integr. Agric., 2012, 11, 235-248.

31. Guo, X. and Zhou, X., Molecular characterization of Alternanthera yellow vein virus: a new begomovirus species infecting Alternanthera philoxeroides. J. Phytopathol., 2005, 153, 694-696.

32. Huang, J. F., Jiang, T. and Zhou, X. P., Molecular characterization of begomoviruses infecting Ludwigia hyssopifolia. J. Plant Pathol., 2006, 88, 83-88.

33. Ha, C., Coombs, S., Revill, P., Harding, R., Vu, M. and Dale, J., Molecular characterization of begomoviruses and DNA satellites from Vietnam: additional evidence that the New World geminiviruses were present in the Old World prior to continental separation. J. Gen. Virol., 2008, 89, 312-326.

34. He, Z. F., Mao, M. J., Yu, H., Wang, X. M. and Li, H. P., First report of a strain of Alternanthera yellow vein virus infecting Eclipta prostrata (L.) L. (Compositae) in China. J. Phytopathol., 2008, 156, 496-498.

35. Mubin, M., Shahid, M. S., Tahir, M. N., Briddon, R. W. and Mansoor, S., Characterization of begomovirus components from a weed suggests that begomoviruses may associate with multiple distinct DNA satellites. Virus Genes, 2010, 40, 452-457.

36. Zaidi, S. S., Shakir, S., Farooq, M., Amin, I. and Mansoor, S., First Report of Alternanthera yellow vein virus from Eclipta prostrata in Pakistan. Plant Dis., 2017, 101, 266.

37. Xie, Y., Zhou, X., Zhang, Z. and Qi, Y., Tobacco curly shoot virus isolated in Yunnan is a distinct species of begomovirus. Chin. Sci. Bull., 2002, 47, 199-201.

38. Li, Z. H., Zhou, X. P., Zhang, X. and Xie, Y., Molecular characterization of tomato-infecting begomoviruses in Yunnan, China. Arch. Virol., 2004, 149, 1721-1732.

39. Swarnalatha, P., Kanakala, S., Manasa, M., Jalali, S. and Reddy, M. K., Molecular characterization of tobacco curly shoot virus infecting tomato (Solanum lycopersicum L.) in India. Pest Manage. Hortic. Ecosyst., 2013, 19, 73-84.

40. Qing, L., Xiong, Y., Sun, X. C., Yang, S. Y. and Zhou, C. Y., First report of Tobacco curly shoot virus infecting pepper in China. Plant Dis., 2010, 94, 637.

41. Venkataravanappa, V., Swarnalatha, P., Lakshminarayana-Reddy, C. N., Mahesh, B., Rai, A. B. and Krishna-Reddy, M., Molecular evidence for association of Tobacco curly shoot virus and a betasatellite with curly shoot disease of common bean (Phaseolus vulgaris L.) from India. J. Plant Pathol. Microbiol., 2012, 3, 148.

42. Shilpi, S., Kumar, A., Biswas, S., Roy, A. and Mandal, B., A recombinant Tobacco curly shoot virus causes leaf curl disease in tomato in a north-eastern state of India and has potentiality to trans-replicate a non-cognate betasatellite. Virus Genes, 2015, 50, 87-96.

43. Chowda-Reddy, R. V., Muniyappa, V., Colvin, J. and Seal, S., A new begomovirus isolated from Gossypium barbadense in southern India. Plant Pathol., 2005, 54, 570.

44. Venkataravanappa, V., Lakshminarayana Reddy, C. N., Devaraju, A., Jalali, S. and Krishna Reddy, M., Association of a recombinant Cotton leaf curl Bangalore virus with yellow vein and leaf curl disease of okra in India. Indian J. Virol., 2013, 24, 188-198.

45. Brown, J. K., Frohlich, D. R. and Rosell, R. C., The sweetpotato or silverleaf whiteflies: biotypes of Bemisia tabaci or a species complex? Annu. Rev. Entomol., 1995, 40, 511-534. 
46. Shah, M. M., Zhang, S. and Liu, T., Whitefly, host plant and parasitoid: a review on their interactions. Asian J. Appl. Sci. Eng., 2015, 4, 48-61.

47. Ellango, R. et al., Distribution of Bemisia tabaci genetic groups in India. Environ. Entomol., 2015, 44, 1258-1264.

48. Singh, S. T. et al., Diversity and phylogenetic analysis of endosymbiotic bacteria from field caught Bemisia tabaci from different locations of North India based on $16 \mathrm{~S}$ rDNA library screening. Infect. Genet. Evol., 2012, 12, 411-419.

49. Fondong, V. N., Geminivirus protein structure and function. Mol. Plant Pathol., 2013, 14, 635-649.

50. Khan, Z. A. and Khan, J. A., Characterization of a new begomovirus and betasatellite associated with chilli leaf curl disease in India. Arch. Virol., 2017, 162, 561-565.

51. Nawaz-ul-Rehman, M. S., Briddon, R. W. and Fauquet, C. M., A melting pot of Old World begomoviruses and their satellites infecting a collection of Gossypium species in Pakistan. PLoS ONE, 2012, 7, e40050.

52. Islam, M. N., Sony, S. K. and Borna, R. S., Molecular characterization of mungbean yellow mosaic disease and coat protein gene in mungbean varieties of Bangladesh. Plant Tissue Cult. Biotechnol., 2012, 22, 73-81.

ACKNOWLEDGEMENTS. This work was supported by the Japan International Cooperation Agency under the project 'Maximization of soybean production in Madhya Pradesh' (2012-2016). We thank K. Taniwaki, S. S. Tomar and S. K. Rao for encouragement and support. We also thank M. Ohnuki for his early guidance and suggestions.

\section{Urban sustainability analysis of Solan district, Himachal Pradesh, India}

\author{
Jyotsana Pandit ${ }^{1,2, *}$, S. K. Bhardwaj ${ }^{1}$ and \\ Anish Kumar Sharma \\ ${ }^{1}$ Department of Environmental Science, University of Horticulture and \\ Forestry, Nauni, Solan 173 230, India \\ ${ }^{2}$ School of Sciences, P.P. Savani University, Surat 394 125, India
}

Urbanization is one of the most significant global trends of modern times, driving and driven by multiple social, economic and environmental processes. Due to uncontrolled urbanization, there is rapid environmental degradation which causes many problems. Scientific assessments can help provide solutions by considering the local realities. Numerous assessment strategies have been suggested such as emerge analysis, material flow analysis, data development analysis

\footnotetext{
*For correspondence. (e-mail: jyotsanapandit@gmail.com)
}

and ecological footprint analysis (EFA). EFA has been implemented as a useful analytical and planning tool for assessing urban sustainability in numerous cities. The aim of this study is to use one of the EFA components, viz. built-up land footprint ( $\left.\mathrm{EF}_{\text {built-up }}\right)$ to evaluate the urban sustainability of Solan district, Himachal Pradesh (HP), India, in terms of settlements. The

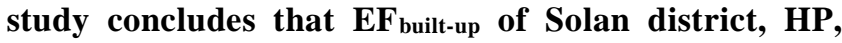
exceeds its biocapacity, resulting in an ecological deficit. Therefore, element of built-up land in Solan district is considered as an unsustainable system.

Keywords: Biocapacity, built-up land footprint, ecological footprint analysis, ecological deficit, urban sustainability.

THE world is increasingly becoming urbanized. About $65 \%$ of the world's population is expected to live in cities by 2025 (ref. 1). Excessive urban sprawl is the source of many problems such as air pollution, crime, housing, noise pollution, traffic jam, shortage of clean drinking water as well as energy ${ }^{2}$. Since the end of the 19th century, the problems posed by modern urban development have emerged in the environmental, social and economic spheres, which have made these communities unstable and forced experts to look for alternative urban development patterns. Modern-day lifestyles are exploiting many natural resources, polluting the environment, increasing social inequality, building tropical islands and causing climate change. In this regard, the term 'sustainability' was first developed by the United Nations in the Brundtland Commission Report, which defines sustainable development as one that meets current needs without compromising the ability of future generations to meet their needs ${ }^{3}$. The problem of achieving sustainable urban development is thus an important challenge. Measuring urban sustainability is an engine of social and economic development, but at the same time focusing on environmental issues is a major challenge for environmental managers and decision-makers ${ }^{4}$.

Urban sustainability is defined as the process by which measurable long-term social development can be achieved through actions in the environment, economic and social magnitude. The use of sustainability indicators is increasingly needed to achieve sustainability ${ }^{5}$. Sustainability indicators are the solid basis for regular and longterm monitoring of progress towards achieving strategic developmental goals and evaluation of various forms of sustainability ${ }^{6}$. They provide past and present trends for any particular problem, and serve as a supportive tool for future decisions ${ }^{6}$. They are the tools needed to develop a strategy and for policy development, to provide a picture of the three dimensions of sustainable urban development: social, economic and environmental. They need to assess the state of sustainable urban development in order to support urban environmental 